\title{
THE PRESENCE OF ARGYROPHILIC GRANULES IN THE PARENCHYMAL CELLS OF THE PARATHYROID GLANDS ${ }^{1}$
}

\author{
RICHARD J. WEYMOUTH AND BURTON L. BAKER \\ Department of Anatomy, University of Michigan Medical School, \\ Ann Arbor, Michigan \\ EIGHT FIGURES
}

Cytological study of the parathyroid glands has been retarded by the lack of a technique for demonstration of parathormone or its precursors within the secretory cells. Several investigators have reported such procedures but thus far, the intracellular material designated as secretion has not been observed in more than a single species and in no case has it been studied when the secretory activity of the gland is accelerated or decelerated by experimental means. Consequently, none of these methods has received general acceptance as an adequate tool for the cytophysiological investigation of the parathyroid glands.

Bobeau ('11) observed many substances within the parenchyma of the parathyroid glands of the horse, including fuchsinophilic bodies, fats, phospholipids, pigment and colloid, all of which he regarded as secretions.

In the rat, osmiophilic secretory material was described by Rosof ('34) after preparation of the glands with the NassonovKolatchev technique. Using a similar procedure, De Robertis ('40, '41) studied the incidence of dark osmiophilic cells during states of experimentally induced hyper- and hypoparathyroidism. He regarded the osmiophilic cells as being the rapidly secreting cells of the gland but in his opinion the os-

${ }^{1}$ This investigation was supported (in part) by rsearch grants (A-131[C]) from The National Institutes of Health and from The Upjohn Company. 
miophilic material was not secretion. Baker ('45) investigated the parathyroid glands of this species when their secretory activity was intensified by ureteral ligation or bilateral nephrectomy. He suggested that the osmiophilia of the dark cells is more probably related to cellular exhaustion than to hypersecretion.

Grafflin ('40) found granules in the cytoplasm of the parenchymal cells of the parathyroid glands of the deer which he believed were secretory substance. They were delineated by fixing in formalin or Zenker-formol and staining with hematoxylin. Bensley ('47) observed pale vacuoles, colloid and other bodies after staining parathyroid glands of the dog with acid fuchsin and methyl green. She regarded these as being secretory material. The cytoplasm of the principal cells of man (Weymouth and Baker, unpublished) and monkey (Cowdry and Scott, '36; Baker, '42) contain basophilic material. Cowdry and Scott ('36) described a decrease in prominence of the basophilic bodies upon administration of viosterol and stated that they are probably "the long sought antecedents of parathyroid secretion." Definite proof for this position has not been presented.

All of the observations cited previously pertain to the principal or chief cells with the possible exception of certain of those made by Bobeau ('11). It is probable that some of the cells described by him were oxyphils. No secretory significance has been attached to the cytoplasmic granulation of oxyphil cells which are present in the parathyroid glands of man and monkey (Baker, '42). This report will show that argyrophilic granules are present in the cytoplasm of the parathyroid principal cells of 7 forms, including man.

\section{MATERIALS AND METHODS}

Table 1 summarizes the species studied. The rats (SpragueDawley strain) and hamsters were bred in our laboratory and maintained on a diet of Purina Laboratory Chow supplemented twice weekly with greens and oranges. The guinea pigs were fed Rockland Guinea Pig ration supplemented with 
greens. Rabbits were purchased from a commercial house and autopsies performed upon arrival. The dogs and monkeys were suppled by other laboratories after being subjected to experimental procedures, which to the best of our knowledge would not modify the function of the parathyroid glands. ${ }^{2}$

TABLE 1

Summary of species studied

\begin{tabular}{|c|c|c|c|c|}
\hline SPECIES & $\begin{array}{c}\text { NO. OF } \\
\text { ANIMALS }\end{array}$ & SEX & AGE & WEIGHT \\
\hline & & & & $\mathrm{kg}$ \\
\hline Rat & 24 & $\sigma$ & 3-12 months & $.15-.20$ \\
\hline Hamster & 8 & 0 & 8-12 months & $.08-.10$ \\
\hline Guinea pig & 3 & 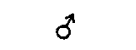 & Adult & $.32-.95$ \\
\hline Rabbit & 3 & 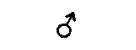 & Adult & $2.08-2.19$ \\
\hline Dog & 3 & $\delta$ and $q$ & Adult & \\
\hline Monkey & 4 & $\sigma$ and $q$ & $\begin{array}{c}\text { Adult } \\
\text { Immature }\end{array}$ & $3.0-9.07$ \\
\hline Man & $\begin{array}{l}1^{1} \\
1^{2}\end{array}$ & $\begin{array}{l}\sigma^{2} \\
\sigma^{2}\end{array}$ & $\begin{array}{l}18 \text { years } \\
60 \text { years }\end{array}$ & $\ldots$ \\
\hline
\end{tabular}

Killed by vertebral fracture.

Generalized granulomatous inflammation of unknown etiology.

All of the parathyroid glands, with some attached thyroid tissue, were fixed in formaldehyde-acetic acid-alcohol fixative. After embedding in paraffin and sectioning at 3-4 $\mu$, the glands were stained according to the Bodian ('36) protargol method. ${ }^{3}$ Some sections of each gland were toned with gold chloride or counter-stained with methylene blue.

2 The authors wish to thank the following members of the University of Michigan Medical Faculty for providing some of the material studied: Doctors Elizabeth C. Crosby, James A. French, Walter J. Nungester, Wayne L. Whitaker and Lauren A. Woods.

${ }^{3}$ We are grateful to Dr. Kay T. Rogers for many useful suggestions in carrying out this procedure. 


\section{OBSERVATIONS}

In the rat, hamster, guinea pig, rabbit and dog, all parenchymal cells are of a single type being comparable with the principal cells of monkey and man. Transformation of them into the water-clear form was not observed in our preparations although water-clear cells have been described in the dog by Bensley ('47). In all of these species argyrophilic granules were observed in the cytoplasm of the majority of the principal cells. Although distributed throughout the cell, the granules were usually aggregated into juxtanuclear masses, conforming closely to the position of the Golgi apparatus (figs. 1, 2, 6, 7, and 8). This arrangement was especially evident in the parenchymal cells which bordered sinusoids. The Golgi apparatus of these cells in the rat (DeRobertis, '40; Baker, '45) and the masses of argyrophilic granules were usually located in the portion of the cell most distal to the blood channel. In a given section, occasional epithelioid cells contained no granules.

With respect to the monkey fig. (5) and man (fig. 3) the granules were found scattered throughout the cytoplasm of most principal cells and were never aggregated in a juxtanuclear position. However, they tended to be more numerous along the cell membrane. Practically no granules were observed in oxyphil cells (fig. 4) or in water-clear principal cells. In fact, the number of granules present in principal cells was inversely proportional to the extent of the clear cytoplasmic areas which mark the development of the water-clear form.

\section{DISCUSSION}

In the rat, hamster, rabbit, guinea pig and dog the disposition of argyrophilic granules was similar in that they frequently accumulated in aggregations close to the nucleus, apparently being in the region of the Golgi apparatus. In the principal cells of the monkey and man the granules were dispersed more generally in the cytoplasm.

Consideration must be given to the individuality of the argyrophilic granules as distinct from other intracellular organelles, in particular the mitochondria and Golgi apparatus. 
It seems certain that these granules are not mitochondria. In the dog (Bensley, '47), rat (Rosof, '34; Baker, '45) and monkey (Baker, '42) mitochondria are filamentous. Without exception, the argyrophilic granules are spherical. Further, mitochondria in the dog (Bensley, '47) and monkey (Baker, '42) frequently are arranged in large numbers at one end of the principal cell, especially the end which borders a capillary. Argyrophilic granules were never so disposed. Finally, argyrophilic granules did not appear in connective tissue cells of the parathyroid gland or in the epithelial cells of the attached thyroid tissue. All of these cells are known to contain mitochondria.

Differentiation from the Golgi apparatus is somewhat less certain since silver impregnation is commonly employed for demonstration of it. To the authors' knowledge, use of the Bodian protargol method has not successfully demonstrated the Golgi apparatus in other cells. It seems unlikely that reduction of silver by this organelle accounts for the black granules. Impregnation of the Golgi body in the parathyroid of the rat by the Aoyama method revealed a membrane rather than granules. Although the Golgi apparatus has not been described for the parathyroid glands of man and monkey, the arrangement of the granules in these species in no way resembled the commonly accepted morphology of the Golgi body as usually observed in other fixed tissues. Finally, no granules or other blackened structures appeared in the attached thyroid epithelium or connective tissue cells, in at least some of which the Golgi body can be demonstrated by other technical procedures with considerable ease.

If the argyrophilic granules are distinct from the Golgi apparatus, their accumulation in the region of this organelle in several species may point to them as possibly being precursors of secretion. In the opinion of many cytologists, the Golgi apparatus is the region of the cell where secretions are synthesized. It is hoped that further evidence concerning the physiological nature of these granules will be derived from experiments in which the secretory activity of the parathyroid glands is altered by experimental means. 


\section{SUMMARY}

Staining of the parathyroid glands of the rat, guinea pig, hamster, rabbit, dog, monkey, and man by the Bodian protargol method revealed blackened granules in the cytoplasm of the principal cells. In the rat, guinea pig, hamster, rabbit and dog they were aggregated frequently into clusters in the juxtanuclear region of the Golgi apparatus. In monkey and man the argyrophilic granules were dispersed more generally throughout the cytoplasm. Oxyphil cells of man and the monkey were devoid of these granules. It is believed that these granules are distinct from mitochondria and probably the Golgi apparatus and, therefore, merit consideration as being secretory precursors.

\section{LITERATURE CITED}

BAKER, B. L. 1942 A study of the parathyroid glands of the normal and hypophysectomized monkey (Macaca mulatta). Am. J. Anat., 83: 47-74.

1945 The structural response of the parathyroid glands to ureteral ligation or bilateral nephrectomy. Anat. Rec., 93: 125-144.

Bensley, S. H. 1947 The normal mode of secretion in the parathyroid gland of the dog. Anat. Rec., 98: 361-382.

BoвEAU, G. 1911 Sur les glandules parathyroïdes du cheval. J. d. l'Anat. et Physiol., 47: 371-413.

BoDIAN, D. 1936 A new method for staining nerve fibers and nerve endings in mounted paraffin sections. Anat. Rec., 65: 89-98.

COWDRY, E. V., AND G. H. SCOTT 1936 Effect on monkeys of small doses of a concentrated preparation of viosterol. Arch. Path., 2Q: 1-23.

DERoBrRTIS, E. 1940 The cytology of the parathyroid glands of rats injected with parathyroid extraet. Anat. Ree., 78: 473-496.

1941 The cytology of the parathyroid and thyroid glands of rats with experimental rickets. Anat. Rec., 79: 417-434.

Grafflin, A. L. 1940 Cytological evidence of secretory activity in the mammalian parathyroid gland. Endoer., $26: 857-859$.

Rosor, J. A. 1934 An experimental study of the histology and cytology of the parathyroid glands in the albino rat. J. Exp. Zool., 68: 121-166. 
PLATE 


\section{PLATE 1}

\section{EXPLANATION OF FIGURES}

The preparations shown in figures 3 to 5 were counterstained with methylene blue. $\times 1040$.

1 Dog. The argyrophilic granules are dispersed throughout the cytoplasm in the majority of principal cells.

2 Rat. Many cells reveal dense accumulations of granules close to the nucleus. The granules in the cell at right center surround the Golgi area.

3 Man. A cluster of principal cells showing a diffuse arrangement of granules with many lying adjacent to the cytoplasmic membrane.

4 Man. Three oxyphils with dark nuclei are shown on the right. As compared with several principal cells on the left, the oxyphils are plactically devoid of granules.

5 Monkey. The principal cells shown contain irregularly dispersed granules which are located in the portion of the cell distal to the sinusoid in the lower left-hand corner.

6 Rabbit. Three cells at the lower left show a dense aceumulation of granules close to the nucleus.

7 Hamster. A large group of granules is located close to the nucleus of the cell at the upper right. Four other cells possess dense clusters close to the nucleus.

8 Guinea pig. Moderately dense accumulations of granules are shown in several cells. 


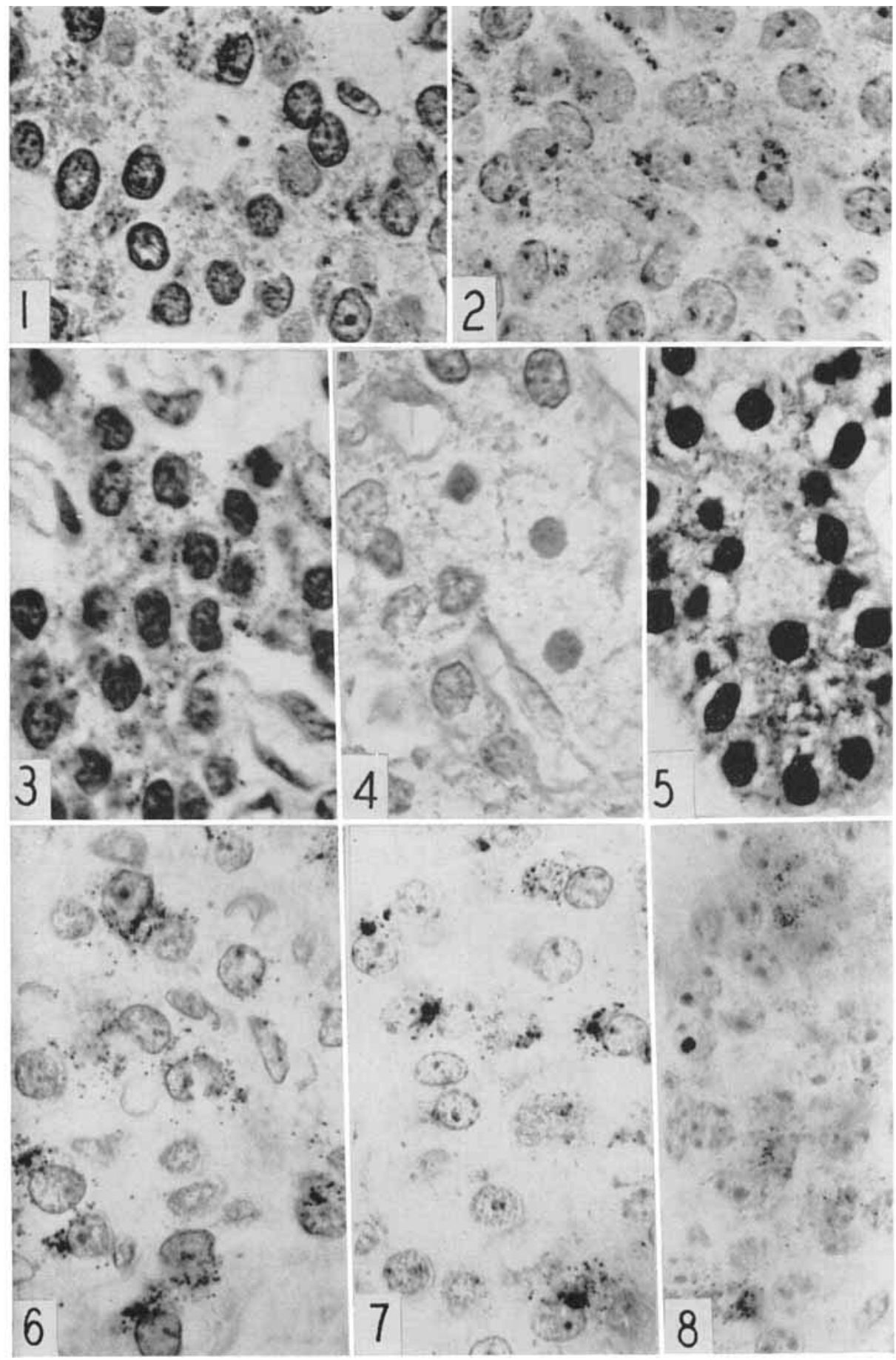

